\title{
Transformasi Tradisi Lisan "Mangokkal Holi” Sebagai Naskah Drama
}

\author{
${ }^{1 *}$ Josua Krismanto Purba, ${ }^{2}$ Servina Halawa, ${ }^{3}$ Sri Dinanta Beru Ginting \\ Email: Purbajosua4@gmail.com² \\ ${ }^{1,2}$ Universitas Prima Indonesia
}

\begin{abstract}
Abstrak
Penelitian ini dilaksanakan untuk mentransformasikan tradisi lisan "Mangokkal Holi" sebagai naskah drama. Penelitian ini menggunakan metode penelitian deskriptif kualitatif yang bertujuan untuk mendeskripsikan secara berurut, faktual dan akurat dengan menggunakan kata-kata atau kalimat. Penelitian mulai dilaksanakan mulai bulan November 2019 sampai dengan Oktober 2020. Tehnik pengumpulan data yang digunakan adalah tehnik simak bebas libas cakap. Data dalam penelitian ini adalah data lisan berupa tradisi lisan "Mangokkal Holi". Sumber data yang dikumpulkan dalam penelitian ini adalah informan dan narasumber dari masyarakat Desa Sitinjak, Onan baru, Samosir. Teknik analisis data menggunakan analisis interaktif, yaitu reduksi, penyajian data, dan penarikan kesimpulan. Tehnik validitas data yang digunakan adalah triangulasi metode dan sumber. Prosedur penelititan meliputi perencanaan, pelaksanaan, dan penyusunan laporan. Hasil penelitian dari tradisi lisan "Mangokkal Holi" terbentuk karena adanya unsur mistis dan penghormatan terhadap leluhur dalam masyarakat suku batak toba, bahwa tradisi ini sangat dijunjung tinggi oleh masyarakat batak toba. Mulanya para leluhur ataupun keluarga inti dari orang yang sudah lama meninggal akan mendatangi keluarga yang masih hidup. Kedatangan dari roh tersebut akan datang melalui mimpi dan pertanda itulah yang biasanya digunakan sebagai alasan pelaksanaan ritual "Mangokkal Holi". Namun tidak seluruhnya begitu, pada objek penelitian ini hanya berfokus pada marga Sianturi. Tradisi lisan yang telah disusun, lalu ditransformasikan oleh peneliti menjadi naskah drama.
\end{abstract}

Kata Kunci : Transformasi, Tradisi Lisan "Mangokkal Holi”, Naskah Drama

\section{PENDAHULUAN}

Tradisi adalah sebuah kepercayaan yang hidup di dalam masyarakat. Kegiatan ini dilakukan untuk sesuatu tujuan tertentu. Seperti, pertuturan adat, mantra, lagu permainan anakanak, bahkan lagu pujian bagi orang yang baru meninggal, dendang untuk berburu binatangbinatang buas. Dalam penyebarannya, tradisi biasanya dituturkan oleh masyarakat kepada kelompok masyarakat lainnya. Pendapat ini didukung oleh (Duija : 2005) Tradisi lisan adalah segala wacana yang disampaikan secara lisan, mengikuti cara atau adat istiadat yang telah memola dalam suatu masyarakat. 
Penyebaran sebuah tradisi tidak akan lepas melalui tuturan masyarakat. Hal inilah sebagai pembentuk sebuah sastra lisan yang dari generasi ke generasi dibagikan melalui pertuturan nenek moyang, kakek-nenek, maupun orang tua. Sastra lisan hadir sebagai karya sastra yang beredar di masyarakat atau diwariskan secara turun temurun dalam bentuk lisan, baik bentuk puisi maupun mitos-mitos serta tradisi dan tidak terlepas dari nilai-nilai yang terkandung di dalamnya, baik itu nilai pendidikan, moral, etika, budaya dan masih banyak lagi nilai-nilai kehidupan yang positif yang sangat penting untuk ditanamkan ke dalam kehidupan sehari-hari. Sastra lisan mempunyai fungsi di tengah masyarakat, fungsi utamanya adalah untuk hiburan (Amir : 2013). Secara umum sastra lisan memiliki fungsi yang bermacam-macam, antara lain sebagai sarana pendidikan, pusat komunikasi, ajang kompetensi sosial, dan fungsi sastra lisan juga dapat mempererat tali persaudaraan di dalam masyarakat.

Pada dasarnya karya sastra adalah sebuah daya pikir sesorang dalam mengekspresikan perasaan hati dan imajinasi pikiran melalui sebuah sastra, baik itu prosa, puisi, naskah drama, dll. karya sastra juga merupakan hasil realisme kehidupan di dalam masyarakat, banyak cerita-cerita yang dialami oleh banyak orang dan ditransformasi menjadi sebuah karya sastra. Maka dari itu tidak dapat lahir sebuah karya sastra tanpa adanya campur tangan dari budaya. Menurut (Astika, dkk : 2014) Karya sastra adalah ungkapan pikiran dan perasaan seorang pengarang dalam usahanya untuk menghayati kejadian-kejadian yang ada disekitarnya, baik yang dialaminya maupun yang terjadi pada orang lain dan kelompok masyarakat.

Tradisi "Mangokkal Holi" merupakan sebuah upacara atau ritual yang dipercayai oleh kebudayaan masyarakat Batak Toba. Pemindahan tulang-belulang atau lebih dikenal oleh orang Batak Toba dengan istilah "Mangokal Holi” adalah pemindahan jasad yang telah menjadi tulangbelulang yang dilakukan oleh suku adat Batak Toba kepada para keluarga yang telah lama meninggal dan jasadnya sudah menjadi tulang. Lalu memindahkan jasad-jasad tersebut kedalam tugu atau muara dengan harapan agar rohnya dipersatukan kembali. Sementara itu, tugu adalah sebuah kuburan yang sangat bersar dan tinggi menjulang keangkasa. Biasanya, sebuah tugu dibuat oleh masyarakat batak untuk menghormati para nenek moyang.

Tradisi "Mangokal Holi" perlu dijadikan naskah drama, karena pada dasarnya sebuah drama sangat berpengaruh bagi perkembangan kreatifitas dan juga berperan dalam kesenian untuk menciptakan sebuah tontonan realisme dari kehidupan dan juga tradisi-tradisi yang ada, serta sebagai ajang penyebaran. Dengan demikian, penelitian ini juga dapat membuka wawasan 
masyarakat, terutama kaum muda untuk lebih mengenal dan mencintai warisan leluhur khususnya tradisi melalui sebuah naskah alur drama. Dalam penelitian ini penulis akan mentransformasikan dari sebuah tradisi yang berjudul "mangokkal Holi" ke dalam penulisan Naskah Drama. Penulis memilih tradisi "mangokkal Holi" sebagai objek dalam penulisan Naskah Drama , karena jika dikaji tradisi tersebut memenuhi aturan dalam nilai struktural yaitu Tema, alur, tokoh, latar dan amanat sehingga dapat dikaitkan dengan penulisan Naskah Drama karena memenuhi aturan dalam penulisan Naskah Drama tersebut. Setiap karya sastra haruslah penulisannya berisi nilai struktural di dalamnya.

Seperti yang dikatakan Nurgiyantoro (2010:18), transformasi adalah perubahan, yaitu perubahan terhadap suatu hal atau keadaan. Jika suatu hal atau keadaan yang berubah itu adalah budaya, budaya itulah yang mengalami perubahan. Penulis menganggap tradisi "mangokkal holi" merupakan sebuah tradisi budaya yang unik sehingga memiliki daya tarik untuk dikaji dan diubah menjadi sebuah Naskah drama, dengan pengkajian itu dilaksanakan maka tradisi tersebut sudah melakukan sebuah perubahan, dimana perubahan tersebut berbentuk menjadi sebuah Naskah Drama.

Keunikannya dari tradisi ini yang masih belum bisa dipercaya dan diterima oleh masyarakat yang tidak diperbolehkan untuk melakukan tradisi tersebut yaitu mengangkat kembali tulang-berulang orang yang sudah lama meninggal namun harus memiliki ikatan kekeluargaan untuk dipersatukan dan dikubur kembali dalam satu kuburan. Dengan mengangkat sebuah tradisi "mangokkal holi" maka kita juga dapat mengetahui lebih dalam mengenai tradisi tersebut. Sehingga sesuatu yang relevan jika di tuliskan dan dikarang menjadi sebuah Naskah Drama.

Penelitian transformasi tradisi "Mangokal Holi” termasuk tradisi yang belum dipulikasi. Untuk melanjuti penelitian tersebut, peneliti tetap konsisten mengenai sastra, khususnya sastra daerah yang harus dikembangkan dan dipublikasikan. Hal tersebut sejalan dengan bidang yang digeluti peneliti, yaitu mahasiswa/i Program Studi Bahasa dan Sastra Indonesia.

Penelitian ini dilakukan untuk mengetahui bagaimana bentuk mitos dalam tradisi lisan "Mangokkal Holi" yang diuraikan oleh masyarakat Desa Sitinjak dan untuk mengetahui bagaimana cara mentransformasi tradisi lisan "Mangokkal Holi” sebagai naskah drama. 
Berdasarkan hal tersebut masalah yang muncul sangat luas. Untuk itu, peneliti membatasi pokok permasalahan pada "Transformasi Tradisi Lisan "Mangokkal Holi” Sebagai Naskah Drama” dan cara mentransformasikan tradisi lisan "Mangokkal Holi” menjadi naskah drama.

\section{METODE PENELITIAN}

Penelitian ini menggunakan metode penelitian deskriptif kualitatif. Penggunaan metode ini bertujuan untuk meneliti suatu objek secara alamiah yang dideskripsikan secara akurat dan sistematis. Semua datanya diuraikan sesuai dengan pengalaman langsung dan hal yang ditemukan pada saat penelitian di lapangan. (Moloeng, 2007). Berdasarkan data dan sumber data yang dibutuhkan dalam penelitian maka penelitian ini tergolong ke dalam penelitian deskriptif karena peneliti langsung terjun ke lapangan untuk mengumpulkan informasi, data yang dibutuhkan dalam peneltian.

Lokasi peneltian dilakukan di Desa Sitinjak, Kec. Onan baru, Kab. Samosir, Sumatera Utara. Penentuan lokasi penelitian ini karena adanya prosesi ritual Mangokkal Holi yang menjadi sumber dari tradisi lisan Mangokkal Holi. Lama waktu penelitian ini berlangsung satu tahun yakni mulai November 2019 - Oktober 2020.

Data dari penelitian ini berupa data lisan tradisi mangokkal holi yang ada di Desa Sitinjak berdasarkan bentuk, fungsi, dan maknanya. Sumber data di dalam penelitian ini adalah informan dan narasumber dari masyarakat Desa Sitinjak. Sumber data tersebut kemudian dicatat dari informan yang menuturkannya. Informan yang dimaksud dalam penelitian ini adalah para orang tua yang sudah lama bermukim dan pernah melaksanakan tradisi mangokkal holi di daerah Desa Sitinjak.

Berdasarkan sumber data, metode yang digunakan dalam pengumpulan data yaitu metode simak. Menurut Surdaryanto (1993:132), metode simak ialah metode yang digunakan dalam penelitian bahasa dengan cara menyimak pengguna bahasa pada subjek yang diteliti.

Setelah pengumpulan data, selanjutnya dilakukan teknik analisis data agar analisis dapat dilakukan dengan tepat. Teknik analisis data yang digunakan dalam penelitian ini menggunakan teknik analisis interaktif. Menurut Miles dan Huberman (1992 : 15-19), adalah pengumpulan data, reduksi data, penyajian data, dan penarikan kesimpulan.

Pada tahap pengumpulan data dilakukan dengan cara observasi, wawancara dan dokumentasi dengan menentukan strategi pengumpulan data yang dipandang tepat dan untuk 
menentukan fokus serta pendalaman data pada proses pengumpulan data berikutnya. Instrument dalam pengumpulan data yaitu berupa daftar pertanyaan yang digunakan untuk mewawancarai informan dan peralatan untuk mendokumentasikan hasil penelitian. Pengumpulan data dilakukan agar dapat memusatkan hasil agar lebih akurat.

Selanjutnya pada tahap reduksi data adanya kegiatan pemilihan, pemusatan, penyederhanaan, dan pengabstrakan data didapat dari sumber penelitian. Pada tahap ini, data yang didapat kemudian dicatat dalam uraian yang terperinci. Selanjutnya data tersebut dilakukan penyederhanaan data dengan membuang data yang tidak mendukung atau tidak berkaitan dengan masalah yang dianalisis. Data yang dipilih berkaitan dengan bentuk tradisi lisan "Mangokkal Holi” di Desa Sitinjak, Samosir.

Pada tahap penyajian data diperoleh berbagai jenis, jaringan kerja, keterikatan, kegiatan atau table serta rangkaian organisasi informasi yang memungkinkan penelitian dilakukan. Data tersebut kemudian dianalisis sehingga diperoleh deskripsi mengenai bentuk tradisi lisan "Mangokkal Holi"

Kemudian setelah penyajian data, maka tahap penarikan kesimpulan dari data yang telah diperoleh sejak awal penelitian. Akan tetapi, kesimpulan yang didapat hanya bersifat sementara berkaitan tentang tradisi lisan "Mangokkal Holi" setelah disimpulkan akan diuji keabsahaannya. Setelah tradisi lisan itu terbentuk maka akan diubah sebagai naskah drama.

Selanjutnya mengecek keabsahan atau teknik validitas data. Validitas data adalah "derajat ketetapan antara data yang terjadi pada objek penelitian dengan daya yang dapat dilaporkan oleh peneliti”. Teknik validitas data dilakukan melalui teknik trianggulasi (Sugiyono, 2006 : 207). Trianggulasi adalah teknik pemeriksaan keabsahan data dengan memanfaatkan sesuatu yang lain diluar data itu untuk keperluan pengecekan data atau sebagai pembandingan terhadap data itu.

Prosedur penelitian adalah penjelasan langkah-langkah yang harus ditempuh dalam suatu penelitian. Hal tersebut karena melalui prosedur penelitian yang telah direncanakan terlebih dahulu, kegiatan penelitian dapat terkontrol dengan baik.

Dimulai pada tahap perencanaan yaitu kegiatan penyusunan rumusan masalah, penyusunan rancangan penelitian dan menentukan cara dalam pengumpulan data. Di dalam penelitian ini terdapat dua rumusan masalah yang disusun, yaitu bagaimana bentuk tradisi lisan "Mangokkal Holi" yang telah dituturkan oleh masyarakat sekitaran Desa Sitinjak , Samosir dan bagaimaan cara mentransformasikan tradisi lisan "Mangokkal Holi” sebagai naskah drama. 
Kemudian pada tahap pelaksanaan antara lain pengumpulan data, pengelompokan data, analisis data dan interpretasi data. Tahap pelaksanaan di dalam penelitian menjadi inti dalam suatu kegiatan penelitian. Pada tahap ini, meliputi pengumpulan data, pengelompokkan data, analisis data dan interpretasi data. Tahap pengumpulan data, peneliti melalui dua tahap, yaitu mengumpulkan data dari informan untuk memperoleh Tradisi Mangokkal Holi secara lengkap. Tahap pengelompokkan adalah tahap peneliti mengelompokkan data yang diperoleh berdasarkan rumusan masalah di dalam penelitian ini. Tahap selanjutnya adalah tahap analisis data dari hasil wawancara. Tahap terakhir adalah interpretasi data yang berupa jawaban dari rumusan masalah yang telah diketahui.

Tahap penyusunan laporan menjadi tahap terakhir dalam prosedur penelitian. Tahap ini dilakukan peneliti setalah semua data yang dibutuhkan telah terkumpul, telah direduksi, telah dianalisis, dan telah disimpulkan. Tahap ini adalah tahap memindahkan hasil penelitian yang diperoleh ke dalam bentuk laporan yang bersifat ilmiah.

\section{HASIL DAN PEMBAHASAN \\ HASIL PENELITIAN}

Pada dasarnya tradisi yang berkembang di Indonesia merupakan tradisi yang memiliki hal unik dan juga bersifat ghaib serta memiliki nilai-nilai luhur. Tradisi yang diadaptasi dalam penelitian ini adalah tradisi Mangokkal Holi. Tentu saja, tradisi ini sudah banyak diteliti oleh para mahasiswa maupun kaum akademisi yang berkecimpung di dunia kebudayaan. Namun, peneliti mengangkat sudut pandang yang berbeda pada penelitian ini, yaitu mengubah tradisi ini menjadi naskah drama yang dapat dipelajari pada dunia akademisi dan juga pementasan yang bersifat pertunjukan.

Data yang didapat untuk menyusun bentuk tradisi ini ialah hasil wawancara dari beberapa informan yang berada di sekitaran tempat lokasi penelitian, tepatnya di Desa Sitinjak, Kec. Onan Baru, Kab. Samosir, Sumatera Utara.

1. Tradisi ini didapatkan peneliti melalui pengumpulan, analisis dan validitas data secara menyeluruh sehingga terkumpullah tradisi "Mangokkal Holi" ini yang telah diuji keabsahan datanya oleh peneliti kepada para informan, penduduk yang berada di sekitaran..... dan juga beberapa sumber referensi yang ada di jurnal berkredibiltas tinggi. Dalam mengumpulkan data 
agar terbentuknya tradisi yang ringkas, peneliti membuat daftar pertanyaan untuk diberikan kepada narasumber (subjek penelitian). Terdapat beberapa kategori dalam wawancara, diantaranya adalah:

a. Kehadiran Tradisi Mangokal Holi tidak bermula pada setiap Marga dalam Suku Batak. Namun dulunya berasal dari kultur Batak pra-Kristen. Bahwa Suku Batak menganggap bahwa tradisi tersebut sangat pantas untuk dilaksanakan dan dikembangkan. Namun alasan dari pihak bermarga sianturi melakukan ritual mangokkal holi karena Mereka menganggap hal tersebut merupakan bentuk penghormatan kepada Leluhur ( Orang Tua), dan menguburkannya kembali di bukit yang tinggi dengan batu yang keras (tambak), hal tsb juga menunjukkan bahwa sikap dalam menjunjung tinggi terhadap Leluhur. Mereka mempercayai tradisi mangokkal holi ini dapat memberkati keluarga yang masih hidup dan memberi kesehatan serta kesejahteraan. Bahkan juga dapat mengeratkan tali kekerabatan/ persauaraan di antara keluarga atau marga.

b. Banyak pro dan kontra yang terjadi akibat dilakukannya ritual "Mangokkal holi". Terkhusus daripada marga Sianturi. Sebahagian dari pomparan marga ini sendiri memiliki alasan tersendiri untuk setuju dan menolak akan pelaksanaan dari ritual ini. Salah satu dari narasumber yang merasakan dampak dari terlaksanannya ritual ini adalah bapak sianturi yang bersikeras akan terlaksananya ritual mangokkal holi disekitar rumahnya. Alasannya karena ritual tersebut dianggap telah melanggar sebuah perintah dalam kitab yang dianutnya, yaitu pantangan terhadap tubuh manusia yang telah mata. Anggapan tersebut juga tersebar dibeberapa daerah.

c. Ketika semua tradisi terlaksana dan tugu sudah disediakan maka pengangkatan tulang berulang tersebut akan dipindahkan ke sebuah tugu (tambak). Namun katanya ketika mangokkal holi ini belum dilakukan, maka leluhur tersebut bisa hidup kembali (menghantui keluarga) dan meminta untuk dipindahkan ketempat yang lebih layak dan istirahat dengan tenang. Biasanya sebelum pembangunan tugu dimulai masih banyak keluarga memohon berkat dari arwah leluhur dengan menyajikan makanan istimewa dan khusus sebagai sesajen. 
d. Punguan marga atau lebih dikenal dengan perkumpulan para marga yang saling berhubungan. Pungan adalah tempat untuk berlindung kepada saudara semarga. Walaupun tidak dari satu orangtua yang sama. Namun pungan dianggap sebagai tempat para saudara yang memiliki moyang yang sama. Pada ritual ini punguan memiliki alasan atas berterimanya ritual ini dimasyarakat luas. Diantaranya adalah, sebagai rasa hormat atas kedua orang tua yang sudah meninggal. Maka dari itu, ketika ingin melakukan ritual mangokkal holi. Pungan akan menjadi pendamping dalam acara tersebut.

Berdasarkan beberapa hasil jawaban wawancara yang didapatkan, peneliti menyimpulkan data yang telah divaliditas oleh informan yang berada disekitaran Desa Sitinjak, Kec. Onan Baru, Kab. Samosir, Sumatera Utara. Alasan Suku batak melakukam tradisi mangokkal holi yaitu Mengenai Nasib keluarga tersebut yang kurang baik, baik itu dalam keberuntungan pekerjaan, misalnya hasil panen yang gagal, susah mendapatkan pekerjaan/jodoh, nasib sial, usaha bangkrut.

Kemudian mengenai hubungan antara keluarga yang merantau dan berdomisili memiliki perbedaan hidup yang berbeda, ada yang baik dan ada yang kurang baik. Dan yang terakhir adalah rasa kebersyukuran atas keberhasilan pendidikan anak anak berhasil. Suku batak tersebut mengartikan bahwa mangongkal holi adalah aktivitas yang dilakukan sebagai penghiburan bagi keluarga yang telah meninggal. Kemudian mengharapkan berkat dari arwah leluhur. Dan juga banyak anggapan bahwa pelaksanaan ritual Mangokal Holi ini bertujuan untuk mendapatkan Hagabean, Hasangapan dan Hamoraon (panjang umur, kehormatan, dan kekayaan).

2. Berdasarkan data yang diperoleh dari wawancara dilapangan. peneliti mengubah hasil wawancara yang didapat menjadi sebuah susunan cerita yang kemudian ditransformasikan menjadi naskah drama. Tujuannya adalah sebagai media penyebaran tradisi dengan cepat dan memudahkan kaum muda untuk mengetahui tradisi lisan tersebut. Berdasarkan tehnik penulisan naskah, maka dapat disusun sebagai berikut :

1) Menentukan tema

Tema yang diangkat dalam naskah drama ini sesuai dengan topik yang diuraikan pada tradisi llisan "Mangokkal Holi". Temanya ialah ritual pengangkatan tulangbelulang. Pada naskah ini telah dideskripsikan dengan jelas temanya ialah sebuah tradisi 
yang dituturkan, karena tradisi lisan yang dituturkan mengandung unsur mistis. Selain sebagai bentuk penghormatan pada ritual "Mangokkal Holi" juga dipercaya sebagai kemakmuran bagi pelaksana ritual tersebut.

(bermula dari anju bermimpi didatangi oleh bapaknya yang sudah meninngal berpulupuluh tahun lamanya. Dalam mimpi itu bapak perbesan untuk melakukan penaikan saring-saring atau dikenal sebagai pemindahan tulang- belulang. Bapaknya juga berpesan agar tulang tersebut dimasukan ke dalam tugu dan digabungkan dengan kakek dan neneknya yang sudah lebih dulu meningga disbanding bapaknya.) *Lampiran

2) Menentukan alur cerita

Alur cerita naskah drama transformasi tradisi lisan "Mangokkal Holi" ialah menerapkan alur maju dalam proses pembuatannya serta memiliki lima tahap cerita yang terdapat di dalam cerita tersebut. Berikut lima jenis tahapan yang dapat diuraikan sebagai berikut;

a) Eksposisi (Pengenalan)

Pengarang memperkenalkan tokoh utama, pembenahan babak serta kaitan antar tokoh yang terdapat dalam cerita. Eksposisi dalam cerita ini terjadi saat Anju menghubungi pihak keluarga dan kepala adat yang (merupakan pemimpin adat setempat, dimana kepala adat inilah yang nantinya akan memimpin ritual pelaksanaan) untuk berkumpul.

(Pagi Hari, ketika mentari masih sangat minim menyinar, iapun menghubungi abang dan kakaknya, mereka ada empat bersaudara, yaitu tiga laki-laki dan satu perempuan. Anju merupakan anak ketiga, saudaranya (perempuan) paling besar (pertama) bernama Badia, kemudian saudaranya (laki-laki) nomor dua bernama Pasu, kemudian saudaranya (laki-laki) paling kecil bernama Patar. Tidak hanya itu juga menghubungi pihak keluarga besar yaitu Tulangnya. Setelah semua di perbincangkan kemudian juga menghubungi Kepala Adat, kemudian semua berkumpul.)*Lampiran

b) Komplikasi (Pengenalan masalah)

Pada bagian ini pengarang atau perancang cerita akan menimbulkan bagian dalam cerita yang dapat memunculkan masalah. Komplikasi yang 
terdapat dalam drama ini adalah, ketika Anju didatangi bapaknya ke dalam mimpi pertama. Anju kaget ketika bapaknya tampak dan sedih ketika bapaknya pergi. Pada mimpi itu, bapaknya meminta Anju melakukan ritual "Mangokkal Holi" (Anju bermimpi pertama kalinya dan menceritakan bahwa ayahnya yang sudah berpuluh tahun lamanya meninggal berpesan untuk melakukan penaikan saring-saring terhadap semua keluarga yang bersangkutan (sudah meninggal). *Lampiran

c) Klimaks (Puncak masalah)

Bagian ini merupakan puncak dari masalah yang dihadapi oleh tokoh utama. Dibagian ini tokoh akan dihadapkan dalam menentukan akhir yang dialaminya. Keberhasilan dan kegagalan biasanya menjadi pemasti akhir yang akan dirasakan tokoh dalam cerita. Klimaks pada drama ini adalah ( ketika Anju gundah, antara percaya atau tidak dan memilih permintaan orangtuanya atau mengabaikan mimpi itu, sebab, jika ia mengabaikannya. Ia telah melanggar titah kelima dari pada kitab kepercayaannya.) *Lampiran

d) Resolusi (Penurunan)

Resolusi adalah tahap penurunan konflik atau masalah yang terdapat dalam cerita. Reslosusi dari drama ini adalah ketika ritual dilakukan dan tulangbelulang diangkat keluar. Saat itu Anju merasa senang dan tenang lantaran permintaan orangtuanya telah dilaksanakan. (Acara pelaksanaan ritual mangokkal holipun akhirnya terlaksanakan. Para ketua adat datang kerumah Anju, kemudian menjelaskan bagaimana ritual, upacara adat dan proses pengangkatan tulang-belulang kemudian di bawa ke Tugu (tambak). *Lampiran

e) Penyelesaian

Pada tahap ini, nasib tokoh ditentukan. Dimana akhir cerita bahagia, buruk atau menanggung. Penyelesaian pada drama ini adalah (Lantaran kisah anju ini, hingga saat ini ritual mangokkal holi disebut sebagai ritual yang sangat berharga dan memiliki nilai penghormatan yang tinggi terhafap ritual, orangtua dan juga yang dihormati) *lampiran 
3) Menyusun adegan

Adegan merupakan bagian dari susunan cerita dalam naskah drama. Pada setiap adegan akan sangat jelas tergambar suasana demi suasana yang berbeda. Pada naskah drama ini, terdapat beberapa adegan yang dirangkum ke dalam tiga bagian terpenting dari naskah tersebut. Bagian pertama, saat anju dihampiri ayahnya di dalam mimpi, Anju mengabaikannya lantaran mengira itu hanya sebuah bentuk kerinduan bahkan rasa percaya tidak percaya. Pada bagian Kedua, Mereka ingin sekali tulang-belulangnya disatukan. Pada bagian ketiga, ritualpun dilaksanakan dan dipimpin oleh ketua adat. Dibagian terakhir/ bagian ketiga, Anju merasa senang dan tenang ketika ritual telah terlaksana. Ia tidak dihampiri lagi oleh orangtuanya.

(Paragraf 1, paragraf 4, paragraf 5, paragraf 6) *Lampiran

\section{4) Dialog dalam tokoh}

Tokoh yang terdapat dalam drama ini berjumlah 11 (sebelas) orang. Karakter pada setiap mempunyai peranan sangat penting untuk membangun cerita. Setiap tokoh juga dipermudah dalam pemberian dialog agar mudah untuk dipahami oleh para pembaca.

Anju : Baik dan Penyayang serta rendah hati Istri Pasu : Baik dan penyabar.

Badia : Baik dan Tegas Pasu : Baik, Tegas

Istri Pasu : Baik dan rendah hati Patar : Baik, rendah hati.

Tulang 1 : Tegas, baik Tulang 2 : Tegas, Baik

Ketua Adat : Baik, rendah hati dan suka menolong. Warga : Baik dan penolong

\section{PEMBAHASAN}

Tradisi merupakan salah satu bentuk kepercayaan dari masyarakat yang dipercayai mempunyai hal-hal mistis terhadap suatu hal-hal yang janggal, baik itu dialami langsung maupun dialami secara tidak langsung. Seperti, mimpi, kesialan, dsb. Berdasarkan hasil penelitian tradisi lisan "Mangokkal Holi" terbentuk dari hasil observasi dan wawancara peneliti dari narasumber, sehingga akurasi dari bentuk tradisi ini dapat diuji langsung kepada para narasumber serta penduduk yang ada di daerah sekitaran Desa Simangulampe, Samosir. 
Kategori yang ditanyakan kepada tiga informan melalui instrumen wawancara, peneliti menyusun dan menarik simpulan mengenai tradisi tersebut. Dengan adanya pengumpulan, analisis dan validitas data. Maka terbentuklah sebuah tradisi lisan pada ritual "Mangokkal Holi" yang akan dijadikan sebagai naskah drama untuk menjadi media penyebaran tradisi tersebut.

Penelitian ini selaras dengan penelitian Nisa Prima, Dkk pada tahun 2019 yang berjudul "Transformasi Mite "Misteri Gang Keramat" Menjadi Naskah Drama Sebagai Bahan Ajar Bahasa Indonesia Siswa Kelas VIII SMP Muhammadiyah 05 Medan Tahun Ajaran 2019/2020”. Penelitian ini digunakan untuk tujuan menggali lebih dalam lagi misteri atau bisa disebut juga sebagai kepercayaan masyarakat yang dilisankan secara lengkap melalui berbagai metode penelitian. Hasil transformasi mite "Misteri Gang Keramat" ini akan dirubah menjadi naskah drama. Namun perbedaan pada penelitian ini ialah objek dan juga bentuk yang diteliti. Yaitu, pada artikel ini pembahasan atau fokus penelitian adalah tradisi.

Penelitian yang mendukung relevansi lainnya yaitu penelitian dari Sri Dinanta Beru Ginting pada tahun 2019 dengan judul "Revitalisasi Legenda Suku Karo"Pancur Kuta" Sebagai Bahan Ajar Kesusastraan Di Prodi Pendidikan Bahasa Dan Sastra Indonesia Universitas Prima Indonesia". Penelitian ini bermaksud untuk mengangkat kembali serta menggali cerita "Pancur Kuta" secara utuh melalui metode dan analisis data yang akurat. Setelah legenda tersebut ditelusuri. Maka legenda tersebut dibentuk kembali menjadi naskah drama dan dijadikan sebagai bahan ajar kesusastraan pada Prodi Pendidikan Bahasa Dan Sastra Indonesia Universitas Prima Indonesia.

Menurut penelitian-penelitian yang relevan itu, pentransformasian Tradisi lisan ini menjadi naskah drama diharapkan dapat tergambar jelas unsur dari caerita, seperti tokoh dan penokohan, alur, gaya bahasa, latar, sampai amanat serta bisa menjadikannya sebagai wadah untuk penyebaran tradisi. Bentuk tradisi tersebut sebelum menjadi naskah drama begitu membosankan dengan tumpuan kata yang memiliki struktur yang mengikuti kaidah bahasa, sedangkan bentuk tradisi yang sudah ditransformasikan menjadi naskah drama akan mudah untuk dipahami dan dimengerti oleh kalangan masyarakat yang luas. Beberapa adegan, dialog, karakter, dan prolog memiliki keselarasan yang begitu memumpuni untuk memikat ketertarikan para pembaca serta dapat digunakan sebagai bentuk hiburan pada pementasan teater. 
Hasil dari transformasi Tradisi lisan "Mangokkal Holi" perlu dijadikan sebagai bahan ajar ataupun dipentaskan sebagai hiburan, karena kedua wadah itu merupakan tempat yang paling tepat untuk penyebarannya. Dengan demikian, peneliti berharap dapat membuka wawasan masyarakat luas untuk lebih lagi mengenal dan mencintai serta mempelajari kultur tradisi warisan leluhur.

\section{SIMPULAN}

Berdasarkan hasil penelitian dapat disimpulkan bahwa tradisi lisan dapat ditransformasikan menjadi naskah drama. Tradisi lisan "Mangokkal Holi" ini hadir pada zaman dahulu yang pertama kali dilakukan oleh leluhur masyarakat batak toba, tidak hanya itu tradisi ini juga banyak mengundang pro dan kontra terhadap masyarakat dan ajaran agama yaitu Alkitab, karena tidak memungkinkan untuk setiap orang beserta pemeluk agamanya daoat mempercayai hal mistis begitu saja. Lahirnya tradisi ini dikarenakan kepercayaan masyarakat batak toba yaitu dapat mendatangkan hal baik bagi keluarga yang melaksanakannya. Serta sebagai penghormatan terhadap leluhur dan juga orangtua yang sudah lama meninggal.

Tradisi lisan "Mangokkal Holi" ini disusun oleh peneliti berdasarkan informasi dari para narasumber dan para penduduk khusus di daerah sekitaran desa Simangulampe. Setelah itu penulis mencoba mentransformasikan kisah tersebut terlebih dahulu dalam bentuk cerpen kemudian menjadikannya sebuah naskah drama sesuai dengan teknik pembuatan naskah drama yang baik dan benar. Hal ini bertujuan untuk menggambarkan cerita dengan jelas dan juga menarik untuk dibaca kalangan luas, sehingga kisah ini tidak tertimbun pada kalangan zaman sekarang.

Hingga saat ini tradisi ini masih tetap dijunjung tinggi, namun tidak banyak masyarakat, khusus suku lain yang mengetahui bahwa tradisi ini benar adanya di Indonesia dan dilaksanakan secara turun temurun. Namun walaupun dianggap sama dengan tindakan Atheisme, tetap menjadi kepercayaan budaya setiap suku yang melaksanakannya.

Berdasarkan hasil penelitian, peneliti memberikan saran bahwa naskah drama ini dapat menjadi daya tarik terhadap penyebaran tradisi lisan "Mangokkal Holi" serta masyarakat dapat lebih mengetahui bentuk tradisi lisan ini dan dapat mengubah tradisi lisan menjadi naskah drama melalui pendekatan pendekatan yang ada dan berkembang saat ini. Lalu, dapat dijadikan sebagai 
pengembangan wawasan mengenai cara transformasi tradisi lisan menjadi naskah drama dengan menggunakan tehnik dan langkah-langkah penulisan yang baik dan benar.

\section{DAFTAR PUSTAKA}

Amir, A. 2013. Sastra lisan Indonesia. Yogyakarta: Penerbit Andi

Astika, I Made dan I NyomanYasa. 2014. Sastra lisan, teori dan penerapannya. Yogyakarta: Graha lmu

Duija, I Nengah. 2011. Tradisi Lisan Maritim sebagai Kekuatan Kultural Masyarakat Bali (Analisi Kosmologi Ritual "samudra" dan "Danu Kertih") dalam Warta ATL. Jakarta: Asosiasi Tradisi Lisan.

Harymawan, RMA. 1988. Dramaturgi. Bandung: Rosda.

Hermawan, Herry. 2012. Menyimak Keterampilan Berkomunikasi Yang Terabaikan. Yogyakarta: Graha Ilmu.

Miles, B. Mathew dan Michael Huberman. 1992. Analisis Data Kualitatif Buku Sumber Tentang Metode-metode Baru. Jakarta: UIP

Moleong, Lexy J. 2007. Metodologi Penelitian Kualitatif. Bandung: PT. Remaja Rosdakarya.

Nurgiyanto, Burhan. 2007. Teori Pengkajian Fiksi. Yogyakarta: Gajah Mada University Press.

Ratna, Nyoman Kutha. 2005. Teori, Metode dan Teknik Penelitian Sastra. Yogyakarta: Pustaka Belajar.

Sudaryanto. 1993. Metode dan Aneka Teknis Analisis Bahasa. Yogyakarta: Duta Wacana University Press.

Sugiyono. 2006. "Metode Penelitian Kuantitatif Kualitatif dan R\&D”. Bandung: Alfabeta. 